\title{
Local Content Requirements in Nigeria's Extractive Sector and the Implications for Sustainable Development
}

\author{
Oyeniyi Abe* $\odot$ \\ University of Huddersfield, Huddersfield, UK \\ o.o.abe@hud.ac.uk
}

\begin{abstract}
This article examines the framework of Nigeria's local content laws and policy, and the implications for sustainable development. The legislation is geared towards safeguarding local productivity and aiding the progressive aspirations of Nigeria's citizens. While commendable in principle, there have been questions about policy articulation, implementation and enforcement mechanisms, especially with regard to the Sustainable Development Goals. The article examines the local content legislation in Nigeria, and how policies have shaped the community-corporate nexus. This exposes the challenges facing extractive resource governance in a jurisdiction such as Nigeria and the discourses that have permeated legal scholarship on the practical deference to local content by non-state actors. It considers that well designed and implemented local content requirements are catalysts for structural development. To achieve sustainable development of its extractive sector, Nigeria requires state-led determination to stimulate economic growth and development. The article argues for continuous consultation as a bedrock for meaningful engagement.
\end{abstract}

\section{Keywords}

Local content requirements, Nigeria, sustainable development, extractive sector

\section{INTRODUCTION}

This article aims to inform debates seeking to understand how local content requirements (LCRs) can create some form of social exclusion if not implemented effectively. The exploration of renewable and non-renewable energies has led to severe human rights violations, often at the hands of state and

PhD (Cape Town). Lecturer in law, Huddersfield Business School, University of Huddersfield; research associate, Centre for Comparative Law in Africa, Faculty of Law, University of Cape Town, South Africa. The author gives special thanks to the anonymous reviewers. 
corporate actors. ${ }^{1}$ These projects have become sites of deep socio-political and cultural contestation among a variety of stakeholders, and often have an impact on the cultural and economic liberalization of marginalized communities. While international human rights instruments oblige state actors to protect, fulfil and respect human rights, ${ }^{2}$ non-state actors have hidden under the protection of the doctrine enshrined in the Westphalian approach to state responsibility, ${ }^{3}$ with a view to avoiding any responsibility to respect human rights or to mitigate effects where violations occur. Local communities, hosts to extractive projects, have lamented being deprived of basic human rights protection, including access to social, cultural, political and economic variables, which ensure a roadmap to sustainable development. Projects that tend to create social exclusion often result in social resistance. This resistance to development projects is a significant facet of the political economy of resource extraction. ${ }^{4}$ The difficulties inherent in decades of mismanaging extractive projects are evident through the ways in which the

1 For the Lake Turkana wind power project in Kenya, see Z Cormack "Kenya's huge wind power project might be great for the environment but not for local communities" (3 September 2019) Quartz Africa, available at: <https://qz.com/africa/1700925/kenyas-hugewind-power-project-in-turkana-hurts-local-people/> (last accessed 8 November 2021). For the Bujagali Dam project in Uganda, see C Irigoyen "The Bujagali Dam project in Uganda" (Centre for Public Impact case study, July 2017), available at: <https://www. centreforpublicimpact.org/case-study/bujagali-dam-project-uganda/> (last accessed 8 November 2021). For the environmental impact of oil exploration in Nigeria, see Environmental Assessment of Ogoniland (2011, UN Environment Programme), available at: <https://wedocs.unep.org/bitstream/handle/20.500.11822/7947/-Environmental\%20Ass essment $\% 20$ of $\% 200$ goniland-2011UNEP_OEA.pdf?sequence=3\&isAllowed=y> (last accessed 8 November 2021). See further O Abe and A Ordor "Local content requirements and social inclusion in global energy markets: Towards business and human rights content" in D Olawuyi (ed) Local Content and Sustainable Development in Global Energy Markets (2021, Cambridge University Press) 392.

2 These instruments include the Universal Declaration of Human Rights (UDHR), International Covenant on Civil and Political Rights, and International Covenant on Economic, Social and Cultural Rights, which are collectively known as the International Bill of Rights. See "International Bill of Rights" (fact sheet no 2, rev 1, 1996), available at: <https://www.ohchr.org/Documents/Publications/FactSheet2Rev. 1en.pdf> (last accessed 8 November 2021). These instruments: evoke states' obligations under the UN Charter to promote human rights and remind the individual of his responsibility to strive for the promotion and observance of those rights; and recognize that, in accordance with the UDHR, the ideal of free human beings enjoying civil and political freedom and freedom from fear and want can only be achieved if conditions are created whereby everyone may enjoy his civil and political rights, as well as his economic, social and cultural rights.

3 The Westphalian Treaty is founded on principles that sought to organize the world into territorially exclusive, sovereign nation-states. See JA Caporaso "The European Union and forms of state: Westphalian, regulatory or post-modern?" (1996) 34/1 Journal of Common Market Studies 29; JG Ruggie "Territoriality and beyond: Problematizing modernity in international relations" (1993) 47/1 International Organization 139.

$4 \quad$ M Conde and P Billon "Why do some communities resist mining projects while others do not?" (2020) 4 The Extractive Industries and Society 681. 
power, interests, incentives and characteristics of political systems shape how extractive industry projects are developed, the impacts of governance interventions and the ultimate outcomes of both. This impact of governance interventions steered states to design several initiatives geared towards the meaningful participation of key stakeholders in the management of their natural resources. One of these initiatives is LCRs, enacted by states to guarantee the inclusion and meaningful participation of the local communities that bear the greatest impact of resource projects.

This article adds to the body of existing literature in further investigating local content, on the one hand as a conversational and policy intervention that is constructive for communities that are hosts to extractive projects, and on the other as an intervention that initiates discourse on the "new modalities of neoliberal governance" of resource projects in African societies. ${ }^{5}$ The article argues that enumerative LCRs are one of the most efficient ways to leverage natural resources for sustainable development. It examines the challenges and prospects of local content legislation implemented by Nigeria, and contrasts this with policy articulations in the extractive sector. The objective is to probe strategy options taken and mechanisms adopted to meet the purpose of increasing economic assistance for local communities. The article achieves this by investigating the institutional stratagems and interests that have promoted the development of local content in resource-rich countries, such as Nigeria. In examining the various legislation and policy, the article assesses how these policies can contrast corporate profit maximization with an incentive to re-invest in communities impacted by extractive projects.

The importance of LCRs in Nigeria's extractive sector is significant. First, Nigeria represents an important country in the development archetype and is a key resource-rich country among developing states. Secondly, Nigeria has implemented differentiated laws and policies anchored on local dynamics of production. For instance, Nigeria's local content is enacted to favour host communities, while its policies guarantee that foreign investors present a plan that produces a net benefit to Nigeria, derived from elements such as employment, resource processing and local participation in the business. However, it appears that responsibility for LCR enforcement and compliance has been delegated to the companies.

In principle, LRCs are designed to favour marginalized indigenous groups and local communities, which are hosts to extractive projects. ${ }^{6}$ Despite legal

$5 \quad$ P Butler "Global governance via local procurement? Interrogating the promotion of local procurement as a corporate social responsibility strategy" in N Andrews and A Grant (eds) Corporate Social Responsibility and Canada's Role in Africa's Extractive Sectors (2019, University of Toronto Press) 151.

6 "Local content policies in minerals-exporting countries: Part 1" (Working Party of the Organisation for Economic Co-operation and Development Trade Committee, 2 June 2017) at 18, available at: <http://www.oecd.org/officialdocuments/publicdisplaydo cumentpdf/?cote=TAD/TC/WP(2016)3/PART1/FINAL\&docLanguage=En $>$ (last accessed 8 November 2021). 
instruments, Nigeria has struggled to effectuate the duty to consult and integrate indigenous peoples in project monitoring and implementation. Consultation has become a particularly nuanced legal topic that implicates indigenous rights under constitutional law principles and the often-nuanced relationship between state versus federal powers. ${ }^{7}$ This article uses "indigenous people" generically to include local communities that are hosts to extractive projects. In most circumstances, these communities are homogenous, with a unique demand that policy objectives are articulated to include them in consultation and participation paradigms.

After this introduction, that article discusses the concept of LCRs, contrasting them with state obligations under trade agreements or international treaties. It further contextualizes the discussions on how local content can create social inclusion in Nigeria's extractive industry. It then examines the legal and policy objectives of local content in Nigeria. It also investigates the sustainability of local content legislation in Nigeria and the role local content plays in effectuating a social licence to operate. This section of the article further highlights the provisions of specific legislation and policy, with a view to investigating a shared approach to the sustainability of LCRs. A conclusion follows.

\section{THE INEVITABILITY OF LOCAL CONTENT REQUIREMENTS}

"Local content" is understood in this article to encompass "local procurement, the employment of local and national people and goods and services (value addition) from local or national firms". ${ }^{8}$ Butler's statement can be understood to mean that, through local content outcomes, resource-rich communities are empowered politically, economically and socially in the ideological construct of adaptive globalism, thereby increasing their stake in extractive industries broadly, and particularly in the supply chain.

Initially, the prebendalist situation, in which most post-colonial African governments found themselves, led to a series of indigenization policies geared towards creating value-added outcomes for their citizens. These policies, couched in the form of structural adjustment programmes, generated governance vacuums. ${ }^{9}$ In Africa's extractive sector, the adjustment programmes empowered multinational companies to dictate operational terms that were inimical to the progress and development of host states. Consequently, indigenous firms lost innovative creations, "access to research, development and skills development", ${ }^{10}$ to international firms, which coalesced around foreign extractive companies to supply goods and services. Local suppliers were left

7 E Wilson "Indigenous rights and resource development in the Arctic: An overview of international standards and principles for consultation, participation and consent" in RI Johnstone and AM Hansen (eds) Regulation of Extractive Industries: Community Engagement in the Arctic (2020, Routledge Press) 9.

8 Butler "Global governance", above at note 5 at 154.

9 Id at 152.

10 Id at 155. 
with the duty of service delivery, with less value-added content and progressive debility in infrastructural development and manufacturing. The challenge is whether obligatory LCRs lead to inadequacies and biases. The attendant effects of these neoliberalist agendas that precluded local contributions to project development gave African states the urge to craft policies that prioritize local content, over international trade rules that foster unfettered access to local markets. For example, one of the fundamental principles of the World Trade Organization (WTO) is the creation of a multilateral trading system, in which trade flows as efficiently and freely as possible. Scholars have argued that Nigeria's Local Content Act violates her national treatment and investment obligations under international treaties. ${ }^{11}$ Arguably, LCRs could appear to violate Nigeria's obligations under WTO and trade-related agreements. ${ }^{12}$ Balancing international economic order with domestic protectionist policies does not obviate any obligation under investment treaties. Indeed, the WTO permits certain exceptions in trade agreements to ensure states meet their obligations under international human rights law vis-à-vis trade obligations under international trade law. The idea is to achieve substantial equality, redressing the structural biases that lead to discrimination. For instance, article XX of the General Agreement on Tariffs and Trade (GATT) allows states to deviate from trade agreements where such deviation will protect public morals, human, ${ }^{13}$ animal or plant life or health. ${ }^{14}$ Such protection gives states an opportunity to craft local content laws to meet the demands of the local populace. The WTO Agreement on Agriculture also furthers protection to local farmers, thereby deferring to local content, especially with regard to competition for land and the reallocation of resources. Despite the dictates of these trade agreements, each state should be able to determine its LCRs in accordance with its own scale of values and in the forms selected by it. The inclusion of human rights provisions in the Nigeria-Morocco bilateral trade agreement (Morocco-Nigeria BIT) creates a semblance of trade relations

11 I Odumosu-Ayanu "Foreign direct investment catalysts in west Africa: Interactions with local content laws and industry-community agreements" (2012) 35/1 North Carolina Central Law Review 65.

12 See DS Olawuyi "Local content policies and their implications for international investment law" in J Chaisse, L Choukroune and S Jusoh (eds) Handbook of International Investment Law and Policy (2019, Springer) 377; A Hilson and J Ovadia "Local content in developing and middle-income countries: Towards a more holistic strategy" (2020) 7/2 The Extractive Industries and Society 253. UJ Orji "The Nigerian oil and gas local content regime and its (non)-compliance with the [Agreement on Trade-Related Investment Measures]" (2018) 9 Journal of Sustainable Development Law and Policy 153.

13 See EB Weiss, JH Jackson and N Bernasconi-Osterwalder Reconciling Environment and Trade (2008, Brill). Deviation for human considerations, based on LCRs, could imply the preservation of a society's fundamental interests, as reflected in public policy and law.

14 See also: General Agreement on Trade in Services, art XIV; Plurilateral Agreement on Government Procurement, art XX111; and Agreement on Trade-Related Aspects of Intellectual Property Rights, art 27.2. 
anchored on equity, justice and fairness. ${ }^{15}$ The Morocco-Nigeria BIT contains several provisions that enshrine corporate social responsibility, human rights and deference to local content. ${ }^{16}$ It obliges investors to carry out social, human and environmental impact assessments, ${ }^{17}$ as well as complying with local laws and regulations, including LCRs. ${ }^{18}$

Proponents of local content argue that failure to enhance LCRs weakens the social contract between the state and the people, resulting in destructive ethnic mobilization, economic predation and deep resentment from host communities to extractive projects. ${ }^{19}$ Consequently, attendant socio-environmental impacts, lack of adequate participation and access to information, land expropriation without compensation and community distrust of state institutions heighten the possibility of resistance to resource projects. ${ }^{20}$

Despite the enactment of local content policies in resource-rich African countries, such as Nigeria, foreign extractive companies continue to frustrate small and medium scale enterprises (SMEs) to the point of bankruptcy. ${ }^{21}$ In some instances, small firms are encouraged to bid for tenders without any guarantee of timely payment in return ${ }^{22}$ and are expected to carry out work without any form of mobilization fee. This challenge transcends completion

15 Reciprocal Promotion and Protection Agreement between the Government of the Kingdom of Morocco and the Government of the Federal Republic of Nigeria (signed 3 December 2016, not yet in force).

16 See further T Gazzini "The 2016 Morocco-Nigeria BIT: An important contribution to the reform of investment treaties" (2017) 3/8 Investment Treaty News, available at: <https:// www.iisd.org/itn/en/2017/09/26/the-2016-morocco-nigeria-bit-an-important-contributionto-the-reform-of-investment-treaties-tarcisio-gazzini/> (last accessed 8 November 2021); P Simons and A VanDuzer "Using international investment agreements to address corporate impunity for human rights violations in extractive industries" (paper presented at the Global Business \& Human Rights Scholars Annual Workshop, Colchester, UK, 12-14 September 2019) at 3.

17 See Morocco-Nigeria BIT, arts 13(3), 14, 15 and 18(2)-(3).

18 See id, art 24(1). See also id, arts 17 (anti-corruption) and 19 (corporate governance and practices). LCRs can be justified under the Agreement on Trade-Related Investment Measures, art IV, which permits developing countries, such as Nigeria, to deviate temporarily from national treatment obligations.

19 A Akonnora and FL Ohemeng "Towards a more accountable resource governance in developing countries: The case of Ghana's oil and gas sector" (2019) The Extractive Industries and Society 1, noting that revenue management requires an effective institutional framework to ensure transparency and accountability.

20 R Lima-de-Oliveira "Corruption and local content development: Assessing the impact of the Petrobras scandal on recent policy changes in Brazil" (2019) The Extractive Industries and Society 9, arguing that local content policies in Brazil's oil and gas sector facilitate industrial development and job creation. See also Abe and Ordor "Local content requirements", above at note 1 .

21 See further M Eboh "Local content, local troubles: How big firms kill small businesses" (24 December 2018) Vanguard (Lagos), available at: <https://www.vanguardngr.com/2018/12/lo cal-content-local-troubles-how-big-firms-kill-small-businesses/> (last accessed 8 November 2021).

Ibid. 
of the contract. ${ }^{23}$ In addition, the procurement process is marred by corruption and there is no guarantee that the LCRs are actually observed. The implication is that severe human rights violations occur within the context of depriving locals of socio-economic variables. These variables necessitate the re-thinking of LCRs as a tool for "employment generation, supply chain development, technological and knowledge spillovers". ${ }^{24}$ This article adopts the view that practical local content policy objectives must fulfil certain key indices. First, in providing employment opportunities for local communities, businesses must include periodic training and knowledge transfers. This will ensure a reduction in unsatisfactory or incompetent skill levels. Secondly, supply chains must create avenues for local communities to be involved in businesses' procurement needs. This extends to directing procurement contracts that favour SMEs. Thirdly, beneficiation ${ }^{25}$ strategies must keep a certain production capacity at the local level, rather than outsourcing levels of production to developed countries. For example, the beneficiation of oil, gas and mining products in Nigeria has the potential to trigger employment opportunities, revenue and technology transfer, resulting in added value for local communities. ${ }^{26}$ Thus, it is argued that LCRs stimulate a form of resource nationalism that creates resource wealth for the people. The next section discusses local content within the context of Nigeria's LCRs and the ramifications for resource management.

\section{Contextualizing local content in Nigeria}

Before the enactment of the Nigerian Oil and Gas Industry Content Development Act 2010, Nigeria relied heavily on foreign procurement of goods and services. ${ }^{27}$ The reliance on foreign sourced materials and the attendant loss of income severely impacted the local economy. Despite the ingenuity of this act, the dissonance towards LCRs is hinged on the fact that local communities believe that their voices are not heard and respected in the decision-making process, as well as on the lack of procedural fairness in contract awarding and project management. ${ }^{28}$ Local communities' confidence

23 Ibid.

24 "Local content policies", above at note 6 at 5 .

25 In the extractive (mining) industry, when a mineral is extracted, beneficiation is the process of adding value to that mineral, which can then be consumed locally or exported.

26 Beneficiation processes include polishing diamonds, removing waste products from minerals, and converting crude oil to oil and gas. These processes not only trigger employment opportunities for local people but also increase the export value of the minerals. See further, G Hopwood (ed) Easing the Way for Investment in Namibia (Institute for Public Policy Research research report, June 2014) at 33, available at: $<$ https://assets.publishing.service.gov.uk/government/uploads/system/uploads/attachment_ data/file/324601/IPPR_Investment_Book_web.pdf (last accessed 4 December 2021.

27 L Atsegbua "The Nigerian Oil and Gas Industry Content Development Act 2010: An examination of its regulatory framework" (2012) 36 OPEC Energy Review 479.

28 A Zhang and TG Measham "Preconditions for social licence: The importance of information in initial engagement” (2018) 172 Journal of Cleaner Production 1559. 
in governance and regulatory approaches is dependent on the belief that these approaches and statutory arrangements are efficient in safeguarding positive extractive resource development. Extractive companies risk sanctions and penalties if they refuse or neglect to activate these LCRs, threatening government intervention where necessary. The intervention of government architecture usually erodes trust in the companies.

The tortious history surrounding the dilemma of local content policies and the recent escalation of oil and gas prices ${ }^{29}$ have again ignited the fear of potentially violent resistance, instigated by environmental degradation and the inequitable distribution of benefits from extraction. ${ }^{30} \mathrm{~A}$ few examples suffice. First, shortly after the amalgamation of Nigeria's Northern and Southern protectorates, the industrial protests between local mine workers and "foreign" workers started at the Enugu State government-owned colliery, which opened in 1915 at Udi and in 1917 at Iva Valley and Obwetti. ${ }^{31}$ The mines operated from a territory historically associated with slavery, shifts in demographics and changes in local politics. According to Brown, ${ }^{32}$ the mines assembled a mix of voluntary workforce, unskilled contract workers, clerical workers and artisans. The disparities in the competence level of the workforce led to a string of protests between, on the one hand, those who considered themselves "traditional rural peasants" who lived close to the mines and, on the other hand, the more knowledgeable "foreigners" who lived farther away from the mines and were considered to be exploiters. The contours of this incident brought to bear the extent to which those considered "local" can assert their rights against exploiters, even if they were considered the same nationality. Secondly, residents of Ihietutu community in Ebonyi State staged a peaceful protest against Eglone Group Ltd, a multinational corporation, relating to its mining operations. ${ }^{33}$ The resilient community not only stopped the mining activities but also successfully prevented the company from further mining activities due to its non-compliance with the terms of the lease signed with the host community. Thirdly, the Nigerian government banned mining activities in Zamfara State, due to the unregulated artisanal mining activities

29 P Stevens "Oil plunges $24 \%$ for worst day since 1991, hits multi-year low after OPEC deal failure sparks price war" (8 March 2020) CNBC, available at: <https://www.cnbc.com/ 2020/03/08/oil-plummets-30percent-as-opec-deal-failure-sparks-price-war-fears.html> (last accessed 8 November 2021). P Domm "Oil prices could go much higher if there is a military escalation after Saudi attack" (16 September 2019) CNBC, available at: <https://www. cnbc.com/2019/09/16/oil-prices-could-go-higher-if-theres-a-military-escalation.html> (last accessed 8 November 2021).

30 A Helwege "Challenges with resolving mining conflicts in Latin America" (2015) 2/1 The Extractive Industries and Society 73.

31 C Brown "Locals and migrants in the coalmining town of Enugu (Nigeria): Worker protest and urban identity, 1915-1929" (2015) 60/1 International Review of Social History 63.

32 Ibid.

33 B Nworie "Nigeria: Ebonyi community protest over unpaid royalty" (25 May 2014) All Africa (Abuja), available at: <https://allafrica.com/stories/201405260165.html> (last accessed 8 November 2021). 
of gold and lead in the community. ${ }^{34}$ These activities have resulted in numerous deaths, kidnappings and other social evils. ${ }^{35}$ Today, Ogoni community, home to extended Shell exploration activities, has prohibited Shell (and any other company) from extractive activities on its land. Shell Nigeria closed its oil facility in Bonny Island, Rivers State ${ }^{36}$ due to insecurity and threats to livelihood. ExxonMobil also shut down its Qua Iboe terminal on 19 May 2016 due to militant threats. ${ }^{37}$

Certainly, these incidents results from the unequal distribution of income from extractive resources. As a response to these conflicts, Nigeria and other stakeholders devised initiatives to enhance the equitable distribution of benefits from extractives and promote less hazardous resource extraction. Initially, the government enhanced greater inclusion of the local community in decision-making processes. Subsequently, foreign extractive companies sought to enhance their transparency through corporate social responsibility practices as a way of engaging more with local communities. ${ }^{38}$ One of the pathways towards delivery of inclusive growth is the enactment of the local content law. ${ }^{39}$ This presupposes that local communities are prioritized in terms of employment, procurement and beneficiation strategy. ${ }^{40}$

34 S Tukur "Zamfara violence: Nigerian govt bans mining activities in troubled state" (7 April 2019) Premium Times (Lagos), available at: <https://www.premiumtimesng.com/news/ headlines/324348-breaking-zamfara-violence-nigerian-govt-bans-mining-activities-in-troubledstate.html> (last accessed 8 November 2021).

35 Ibid.

36 H Uguru and M Faul "Shell Nigeria shuts oil terminal as attacks cut production" (11 May 2016) Seattle Times, available at: <https://web.archive.org/web/20161003154009/http:/ www.seattletimes.com/business/shell-nigeria-shuts-oil-terminal-as-attacks-cut-productio $\mathrm{n} />$ (last accessed 8 November 2021).

37 J Renshaw, L George and S Falush "Nigeria's Qua Iboe crude oil terminal closed, workers evacuated - traders” (19 May 2016) Reuters, available at: <https://www.reuters.com/article/ nigeria-qua-outages/nigerias-qua-iboe-crude-oil-terminal-closed-workers-evacuatedtraders-idUSL5N18G59U> (last accessed 8 November 2021).

38 See the French "duty of vigilance" law, Law No 2017-399 (27 March 2017), which creates a broad responsibility to prevent human rights and environmental impacts by companies of a certain size. The law also regulates activities of parent companies and their subsidiaries, suppliers and subcontractors wherever they are located. See also the UK's Modern Slavery Act 2015.

39 See for instance, Nigerian Oil and Gas Industry Content Development Act, secs 13 and 30.

40 As of September 2019, despite its oil and gas wealth, Nigeria recorded one of the world's highest unemployment rates, at $23.1 \%$. To tackle the issue of unemployment, Nigeria must increase employment by at least $4 \%$, which translates as a minimum of 3 million new jobs annually. See further, "Services sector holds key to tackling unemployment challenge - PwC" (PwC press release, 4 June 2018), available at: <https://www.pwc.co $\mathrm{m} / \mathrm{ng} / \mathrm{en} /$ press-room/services-sector-holds-key-to-tackling-unemployment-challengep.html> (last accessed 8 November 2021). See also "Nigeria unemployment rate" Trading Economics, available at: <https://tradingeconomics.com/nigeria/unemployment-rate> (last accessed 8 November 2021). 


\section{LEGAL AND POLICY OBJECTIVES OF LOCAL CONTENT IN NIGERIA}

\section{Local content in Nigeria's extractive industry}

Unquestionably, Nigeria is the largest producer of oil and gas in Africa. ${ }^{41}$ From the available data, Nigeria's oil industry accounts for about 92 per cent of its total exports, generating a value equivalent to 70 per cent of its revenue. ${ }^{42}$ Despite the high turnover from the proceeds of oil resources, there have been concerns and debates as to whether such proceeds benefit the populace. ${ }^{43}$ In part, questions have been raised regarding the value of proceeds from oil production in terms of taxes, royalties and fees, and whether the local community benefits from the presence of international oil and gas operators through procurement, employment and the delivery of social services. ${ }^{44}$ Furthermore, local workforces have been increasingly vulnerable because of the nature of their work. ${ }^{45}$ In some instances, what remains of unionized worker cohesion and solidarity has evoked conflict at the local level, as workers mobilize for greater equity in the global value chains in which they hold the most precarious positions.

Nigeria has committed to addressing some of these teething problems through the adaptation of some intervention frameworks. ${ }^{46}$ For instance,

41 "Oil production in Africa as of 2020, by country" Statista, available at: <https://www.statis ta.com/statistics/1178514/main-oil-producing-countries-in-africa/> (last accessed 8 November 2021).

42 V Kiprop “Biggest exports of Nigeria” (December 2020, WorldAtlas), available at: <https:// www.worldatlas.com/articles/biggest-exports-of-nigeria.html> (last accessed 8 November 2021).

43 C Hufstader "Where does oil money go? I went to Nigeria to find out" (20 July 2015, Oxfam), available at: <https://firstperson.oxfamamerica.org/2015/07/where-does-oil-mo ney-go-i-went-to-nigeria-to-find-out/> (last accessed 8 November 2021).

44 Ibid.

45 D Rodrik The Globalization Paradox: Democracy and the Future of World Economy (2011, WW Norton).

46 See O Abe "The feasibility of implementing the United Nations Guiding Principles on Business and Human Rights in the extractive industry in Nigeria" (2016) Journal of Sustainable Development Law and Policy 137. Some initiatives have called for more openness and transparency in extractive resource management. For instance, the Extractive Industries Transparency Initiative (EITI) is a multi-stakeholder approach that promotes openness, transparency and accountability in the management of natural resources in the decision-making process. Member states are obliged to disclose information on tax payments, licences and contracts. Nigeria not only signed the initiative, but enacted the EITI Act 2007 to pave the way for the initiative to be implemented. The Publish What You Pay coalition aims to promote transparency. It was launched in Nigeria in 2004, facilitating the implementation of the EITI process. The Open Government Partnership (OGP) is a multilateral partnership that aims to "secure concrete commitments from governments to promote transparency, empower citizens, fight corruption, and harness new technologies to strengthen governance"; Nigeria is currently implementing 14 commitments from the OGP Nigeria National Action Plan (2017-19), which is available at: <https:// www.opengovpartnership.org/wp-content/uploads/2017/05/Nigeria_NAP_2017-2019.pdf> 
the Nigerian Oil and Gas Industry Content Development Act 2010 (NOGICDA) aims to increase indigenous participation in the oil and gas industry by prescribing minimum standards for the use of local services and materials, and promoting the transfer of technology and skills to Nigerian labour in the industry. The act was designed not only to guarantee preference for local operators in the award of oil blocks and contract projects, ${ }^{47}$ but also demands that oil and gas companies give preference to locally manufactured products and equipment when such products and equipment are comparable to their international counterparts. ${ }^{48}$ International oil companies are obliged to: promote education; transfer skills, technology, and research and development; and meet the set minimum technology requirements for training indigenous companies on how to participate better in the oil and gas industry. ${ }^{49}$ Here, states must work closely with universities, research institutes and extractive firms to develop specific types of skills, particularly in cutting-edge technologies utilized by firms. Companies are better suited to meet local demands when there is a deliberate integration of social and environmental interests in their business operations and interactions with stakeholders. In essence, ethical responsibility, which transcends mere compliance with legal requirements, ensures that companies respect a community's social needs and ethical norms.

To interact better with the local community, Kemp proposes four models for corporations to adapt to be able to engage actively with the community. ${ }^{50}$ The first involves interacting with the community through formulating and disseminating information to stakeholders. For instance, local suppliers' capabilities must be periodically assessed to ensure they are able to keep up with the supply chain, with training given to local suppliers to enable them to respond effectively to complex tenders. The second model entails identifying possible risks and ways to counteract negative publicity. The challenge with extractive projects in weak zones is that details about the projects are shrouded in secrecy, allowing for speculation. Transparency, reporting

contd

(last accessed 8 November 2021). The Natural Resource Charter is a set of principles designed for civil society and government, and details the best approach for harnessing the opportunities created by extractive resource governance. It is generally prescriptive and indicates what can make countries successful in terms of positively managing their extractive resources. It is available at: <https://resourcegovernance.org/approach/naturalresource-charter> (last accessed 8 November 2021). Other initiatives include the: UN Global Compact, available at: <https://www.unglobalcompact.org> (last accessed 8 November 2021); and OECD Guidelines for Multinational Enterprises (2011), available at: $<$ https://www.oecd.org/daf/inv/mne/48004323.pdf> (last accessed 8 November 2021).

47 NOGICDA, sec 3(1).

48 Id, secs 10 and 12.

49 Id, secs 37 and 40(1).

50 D Kemp "Community relations in the global mining industry: Exploring the internal dimensions of externally oriented work" (2010) 17/1 Corporate Social Responsibility and Environmental Management 1. 
requirements and enforcement mechanisms are usually missing from publicly available information, thereby leading to undesirable publicity for the company. The third model advocates better dialogue between the company and the local community, taking into consideration people with lesser power. Consultation and meaningful engagement provide a basis for the provision of clear, accurate and timely information to locals in respect of potential impacts on their community. To fulfil the right to participate, local communities must be able to express their views freely and fairly, without any form of coercion, manipulation or use of force. This is the trademark of LCR compliance. The fourth model focuses on taking advantage of the people's input during decision-making.

The first two models are usually used by companies when interacting with the local community, whereas the latter two are rarely practised as they are more nuanced. These models create systems that enhance the understanding of the local community's interests, building bridges between the community and the company: a pathway to attaining a social licence to operate (SLO). Thus, adopting the models maximizes profits for all stakeholders and facilitates organizational change, supporting the interaction between the company and the community during the decision-making process. ${ }^{51}$ An SLO enables the local community and other stakeholders slowly to trust a company and its operations. In return, the company operates responsibly by guaranteeing environmental sustainability and employment generation for the local community. Businesses that obtain legal licences through concessions are only certain to utilize the licence if local content measures exist. ${ }^{52}$

\section{Local content legislation in Nigeria's extractive industry}

Nigerian local content initiatives require "an exhaustive systemic approach that would assess local content levels, identify constraints, develop clear policies and processes to stimulate growth, and clearly define the roles and responsibilities of stakeholders". ${ }^{33}$ Nigeria introduced laws and policies governing local content requirements that will ensure foreign companies give

51 D Kemp et al "Just relations and companies: Community conflict in mining" (2011) Journal of Business Ethics 93.

52 K Moffat et al "The social license to operate: A critical review" (2016) 89 Forestry 477; W Allen et al Building Engagement and Social Licence: Unpacking Social Licence to Operate and Partnerships Developing Rubrics for Guidance and Assessment" (Biosecurity New Zealand technical paper no 2019/17, MPI 18607 project report) at 3, available at: <https://www.myrtlerust.org.nz/assets /Uploads/Building-engagement-and-social-licence-Unpacking-Social-Licence-to-Opera..-.pdf> (last accessed 8 November 2021); J Morrison "Business and society: Defining the 'social license"” (29 September 2014) The Guardian, available at: <https://www.theguardian.com/ sustainable-business/2014/sep/29/social-licence-operate-shell-bp-business-leaders> (last accessed 8 November 2021).

53 P Heum et al Enhancement of Local Content in the Upstream Oil \& Gas Industry in Nigeria (SNF report no 25/03) at 2, available at: <https://openaccess.nhh.no/nhh-xmlui/bits tream/handle/11250/164539/R25_03.pdf?sequence=1\&isAllowed=y> (last accessed 8 November 2021). 
preference to local products and citizens, while procuring goods and services to be used in the extractive industry. The evolution of local content rules in Nigeria has had a tortuous history. For instance, in 2006, Nigeria introduced a comprehensive local content policy that failed to achieve "local participation due to lack of enforceability" in the extractive industry. ${ }^{54}$ An examination of the sustainability of subsequent local content policies follows.

Nigerian Minerals and Mining Act: In Nigeria's mining sector, the Nigerian Minerals and Mining Act 2007 (NMMA) regulates the exploration and exploitation of solid materials in Nigeria. Section 1(1) of the act vests all land, property and control of all mineral resources within Nigeria's contiguous continental shelf in the government. In administering the act, the minister for solid minerals must ensure the sustainable development of Nigeria's mineral resources. ${ }^{55}$ This development extends to compliance with community development agreements (CDAs), which is a major strength of the NMMA. ${ }^{56}$ In exploiting minerals, there is an equitable balance between foreign and indigenous interests. ${ }^{57}$ Furthermore, the minister is to initiate investment-friendly local content measures for mining projects ${ }^{58}$ and facilitate the development of indigenous technical and professional manpower necessary for mining. ${ }^{59}$

Importantly, the NMMA requires a CDA between the mineral title holder and the host community. The essence of a CDA is for mine lessees to enter into a binding agreement with their host community for the purpose of guaranteeing the delivery of social and economic benefits to the community. ${ }^{60}$ The provision of social and economic benefits extends to ensuring education, employment, support for and development of SMEs. ${ }^{61}$ The CDA is subjected

54 B Asiago "Fact or fiction: Harmonizing and unifying legal principles of local content requirements" (2016) 34/3 Journal of Energy \& Natural Resources Law 337; C Nwapi "Corruption vulnerabilities in local content policies in the extractive sector: An examination of the Nigerian Oil and Gas Industry Content Development Act 2010" (2015) 46 Resources Policy 92.

55 A Naibbi and M Chindo "Mineral resource extractive activities in Nigeria: Communities also matter!" (2020) 8/9 Journal of Geoscience and Environment Protection 212. NMMA, sec 4(a).

56 Id, sec 4(c). See also L Raima "Reinventing CSR in Nigeria: Understanding its meaning and theories for effective application in the industry" (2018) 13 Redefining Corporate Social Responsibility (Developments in Corporate Governance and Responsibility) 143.

57 See further GK Foster "Foreign investment and indigenous peoples: Options for promoting equilibrium between economic development and indigenous rights" (2012) 33/4 Michigan Journal of International Law 628. See also NMMA, sec 4(e). Nigerian Minerals and Mining Regulations 2011, regs 11 and 13 oblige mining leaseholders to fulfil all obligations relating to compensation and the performance of social obligation; reg 21 prohibits the operator from using the mining site in a manner that contradicts LCRs.

58 NMMA, sec 4(q).

59 Id, sec 4(r). Id, sec 19 creates a Mineral Resources and Environmental Management Committee that advises the minister on community human rights infringement, including pollution and land degradation.

60 Id, sec 116. See further Abe and Ordor "Local content requirements", above at note 1.

61 Abe and Ordor, id at 394. 
to a five-year periodic review, providing a platform for consultative and monitoring frameworks between the host community and mineral title holder. As a condition precedent before any extractive project commences, the CDA provides a valuable framework for exploration minerals in Nigeria, with particular reference to local content realities. The enforceability of CDAs makes them a veritable tool in the realization of LCRs. ${ }^{62}$

Nigeria Oil and Gas Industry Content Development Act: The NOGICDA defines "Nigerian content" to be a "quantum of composite value added to or created in the Nigerian economy by a systematic development of capacity and capabilities through the deliberate utilization of Nigerian human, material resources and services in the Nigerian oil and gas industry". ${ }^{63}$ Under the NOGICDA, while compliance with LCRs forms a major criterion for the award of a licence to operate, ${ }^{64}$ the act explicitly obligates all regulators and operators in the oil and gas industry to give preference to Nigerian content in executing their operations. ${ }^{65}$ The act gives first consideration to Nigerian independent operators when awarding oil blocks, licences and other projects in the industry. In fact, exclusive consideration is granted to Nigerian indigenous operators that own equipment necessary to operate on land and in swamp oil areas. ${ }^{66}$ The act obliges an operator to craft a content plan detailing how the project will promote local content. ${ }^{67}$ Under the act, the Content Development and Monitoring Board (Monitoring Board) has the discretion to conduct a public review for such a plan. This is important for a variety of reasons. For example, a community relying heavily on a company for water, roads and schools might create a false narrative of LCR enforcement, even though the employment of locals is minimal or non-existent. Extractive industries' operational sites are often situated in spaces close to local people. ${ }^{68}$ Furthermore, their projects sometimes infringe on a local community's places of cultural attachment, spiritual affinity and emotional importance. Where this is not settled diplomatically, locals could develop an ownership stigma of resisting extractive projects. To prevent these infringements, the NOGICDA requires an operator to submit to the Monitoring Board a list detailing how Nigerian content has been met in the execution of a contract. ${ }^{69}$ Furthermore, an operator is

62 E Ekhator "Regulating the activities of oil multinationals in Nigeria: A case for selfregulation” (2016) 60/1 Journal of African Law 1.

63 NOGICDA, sec 106.

64 Atsegbua "The Nigerian Oil and Gas Industry", above at note 27 at 481 . See also id, sec $3(3)$.

65 C Nwapi, C Ezeigbo and O Oke "Developments in beneficial ownership disclosure in the extractive industries in Nigeria" (2021) 8/1 The Extractive Industries and Society 443.

66 See NOGICDA, secs 2 and 3.

67 Id, secs 4 and 12.

68 Conde and Billon "Why do some communities", above note 4 at 683. See further id, sec 27.

69 Id, sec 24 
expected to submit to the Monitoring Board a succession plan for all positions not held by Nigerians and a detailed plan for how Nigerians will understudy each incumbent expatriate for a period not exceeding four years so that, at the end of the four years, the position will be domesticated, that is, occupied by a qualified Nigerian. ${ }^{70}$

Failure to recognize LCRs could lead to a range of marginalization: political, economic, social exclusion and cultural. If adequate protection is not guaranteed under local content laws, marginalized communities might not understand the technicalities of extractive projects. Discrimination on the basis of ethnicity, gender or group has deep-seated untoward consequences. Communities that have been promised good jobs and development may be trusting of companies that engage in inadequate corporate social responsibility rather than an integrated form of local content.

The Petroleum Industry Act: On 16 August 2021, President Muhammadu Buhari signed the Petroleum Industry Act 2021 (PIA) into law. This comprehensive and holistic act regulates the financial, administrative and operational activities of the petroleum industry. The PIA seeks to "create efficient and effective governing institutions", ${ }^{71}$ and facilitate transparency and accountability, good governance, and sustainable administration of the petroleum industry. ${ }^{72}$ The PIA effectively repeals the Associated Gas Reinjection Act $1979,{ }^{73}$ while some laws will continue to apply until the expiry of any licences and oil mining leases granted under them: ${ }^{74}$ the Petroleum Act, Oil Pipelines Act and Petroleum Profit Tax Act. ${ }^{75}$ Subject to certain exemptions, these laws will continue to apply as if they had been issued by the Nigerian Upstream Regulatory Commission (the Commission) or Nigerian Midstream and Downstream Petroleum Regulatory Authority (the Authority) under the PIA, unless they are revoked or replaced by an amendment to the PIA. ${ }^{76}$ The PIA is instructive for LCRs in several ways. First, section 234 of the PIA provides socio-economic benefits from petroleum activities to host communities. ${ }^{77}$ The act also promotes a robust, peaceful, and harmonious relationship between operators and host communities. It establishes an operational level grievance mechanism to settle disputes between project proponents and host communities. ${ }^{78}$ Furthermore, section 235 introduces the requirement

70 Id, sec 32.

71 PIA, sec 2.

72 Ibid.

73 Id, sec 310.

74 See further id, sec 311(9).

75 Also included is any subsidiary regulation made under any of these laws and the laws will remain in operation until they are repealed or revoked under the PIA.

76 See PIA, sec 311(1).

77 The Nigerian Constitution provides that $13 \%$ of the revenue from the federation account is paid to oil-producing states. 
for host community development trusts for the benefit of host communities. These trusts are designed to finance infrastructure developments, accelerate economic opportunities and promote the sustainable development of host communities. ${ }^{79}$ Each project promoter must make an annual contribution of 3 per cent of its annual operating expenditure in the preceding financial year to the relevant trust. ${ }^{80}$ Project operators have 12 months to establish a trust. ${ }^{81}$ Contributions are to be applied for the "development of the economic and social infrastructure" of the host community. ${ }^{82}$ This is intended to safeguard the interests of host communities and encourage transparency and accountability in the operations of the industry. However, there are concerns from stakeholders, especially local communities, whether the 3 per cent operating expense allocated to host communities is adequate and whether it is more than the 30 per cent profit share to be used for exploratory development in the "frontier basins". ${ }^{83}$ Comparatively, the 30 per cent profit share for oil exploration in the frontier basins is about USD 400 million per annum, ${ }^{84}$ while the 3 per cent allocated to host communities represents approximately USD 500 million annually. ${ }^{85}$ Secondly, within one year or six months after the grant of a licence or lease respectively, licensees or lessees operating in the upstream and midstream petroleum sector must submit to the Commission an environmental management plan in respect of the projects that require environmental impact assessment. ${ }^{86}$ This plan is expected to contain the licensee's written environmental policy, objectives and targets, and commitments to comply with relevant laws, regulations and guidelines. The plan should also investigate, assess and evaluate the impact of the licensee's proposed activities on the environment. It is also the responsibility of the licensee or lessee to rehabilitate and manage negative impacts of the project on the environment. Thirdly, in addition to the PIA's objectives, which are anchored on transparency, efficiency, sustainable development and good governance accountability, section 83 broadly provides for the full discourse of information on contracts, licences and leases with the Nigerian National Petroleum Company. Such contractual information must be provided to the

\footnotetext{
79 Id, sec 239.

80 Id, sec 240.

81 Id, sec 236

82 Id, sec 239.
}

83 See id, sec 9 , providing that at least $30 \%$ of the profit generated by the proposed Nigerian National Petroleum Company Limited will be allocated to oil exploration in the "frontier basins". K Oyero "3\% to host communities more than 30\% profit share for oil exploration in Sokoto, others - Kyari” (24 August 2021) Punch, available at: <https://punchng.com/3-tohost-communities-more-than-30-profit-share-for-oil-exploration-in-sokoto-others-kyari/?utm_ medium=Social\&utm_source=Facebook\&fbclid=IwAR3bOh-dY0Cgf4NHckSCcgRxLIfWT3zx8g V8F3Jv6VUc-IcoMJBXiE50J3M\#Echobox=1629822277> (last accessed 8 November 2021).

84 Frontier basins include the Chad Basin, Gongola Basin, Sokoto Basin, Dahomey Basin, Bida Basin, Benue Trough and Anambra Basin.

85 See note 83 above.

86 PIA, sec 102. 
Commission and published on the Commission's website within one year of the licence or lease being granted. ${ }^{87}$

The PIA preserves certain laws, subsidiary legislation and regulations otherwise repealed by the PIA, in so far as they are not inconsistent with the PIA. These laws, regulations and directions will continue to operate as if they had been issued by the Commission or Authority until revoked or amended by the PIA. ${ }^{88}$ The PIA vests ownership of all petroleum resources and the resultant revenue in the federal government. ${ }^{89}$ Granting the state exclusive ownership over natural resources could, however, hamper the state-corporate-community relationship, as the debate continues over who owns natural resources. ${ }^{90}$ Under the Petroleum Act, the minister makes regulations and provides generally for "matters relating to licenses and leases granted under the Act". ${ }^{91}$ Such matters could include "safe working, the prevention of pollution of water courses and the atmosphere, and the making of reports and returns (including the reporting of accidents) and inquiries into accidents". ${ }^{92}$ The act does not specifically include the local community in the granting of oil and mining leases, but the PIA subjects the minister's actions to oversight by the Commission. One critical challenge is determining the mechanisms through which local participation in decision-making can enhance legitimacy. There is a disconnect between corporate actors and the local community. To guarantee the effectiveness of LCRs, local actors must be involved in policy decisions. ${ }^{93}$ Furthermore, any licensed company must be required to incorporate and provide for due diligence requirements and a human rights impact assessment. Furthermore, the Petroleum (Drilling and Production) Regulations 1969 require human rights content, which makes local community participation and consultation imperative before any oil prospecting or mining activity starts. Section $1(2)(\mathrm{h})$ of these regulations, which provides for the employment quota of Nigerians in the oil and gas industry, should be amended to enhance the position of the community local to the extractive activity.

National Petroleum Policy 2017: As obliged under the NMMA, the minister of petroleum resources published two policy documents: the National Gas

87 See generally id, sec 83.

88 Id, sec 311. The Petroleum Act 1969 is one such law.

89 PIA, sec 1.

90 See further: L Aladeitan "Ownership and control of oil, gas, and mineral resources in Nigeria: Between legality and legitimacy” (2012) 38 Thurgood Marshall Law Review 159; D Cambou and S Smis "Permanent sovereignty over natural resources from a human rights perspective: Natural resources exploitation and indigenous peoples' rights in the Arctic" (2014) 22/1 Michigan State International Law Review 347.

91 Petroleum Act, sec 9(1)(b)(iii).

92 Ibid.

93 See SC Jagers et al "The impact of local participation on community support for natural resource management: The case of mining in northern Canada and northern Sweden" (2018) 9 Arctic Review on Law and Politics 124. 
Policy ${ }^{94}$ and the National Petroleum Policy. ${ }^{95}$ Both documents are geared towards positive development outcomes for Nigeria. The main purpose of the National Petroleum Policy is for Nigeria to be a nation "where hydrocarbons are used as a fuel for national economic growth and not simply as a source of income". ${ }^{96}$ One of its objectives includes minimizing environmental degradation in pursuit of oil exploration in the country. ${ }^{97}$ With particular reference to local content, the policy provides for the inclusion of local communities in infrastructure, social and petroleum developments in the Niger Delta area. ${ }^{98}$ The government will also focus on human capital development as a means of increasing local content. ${ }^{99}$ The policy also aims to overhaul the procurement process, award marginal fields to indigenous people and develop human capital to further increase local content. ${ }^{100}$ For so long as these remain policy documents, not enactments of the National Assembly, their progressive realization and enforcement remain in doubt. Indeed, they have not been recognized by the courts. ${ }^{101}$

\section{Sustainability of local content legislation: Myth or reality?}

Under Nigeria's Constitution 1999 (the Constitution), the administration of mining activities (including oil and gas) falls under federal authority. ${ }^{102}$ By design, LCRs provide for the general duty to consult host communities to extractive projects. Consequently, government policies and objectives are geared towards incentivizing technological innovations, expanding economic benefits and minimizing or mitigating probable adverse impacts on local populations. Thus, certain provisions construe local content to mean policies aimed at the interests of host communities and "develop[ing] the socioeconomic conditions of historically disadvantaged citizens". ${ }^{103}$

In the Niger Delta, for instance, local content is derived from the adequacy and quality of the consultation process before the project contract was concluded. Hence, project developers are obliged to provide detailed and adequate information on their consultation with the local community during

94 This policy was approved on 28 June 2017.

95 This policy was approved on 19 July 2017.

96 “The National Petroleum Policy (NPP)" (August 2017, KPMG), available at: <https://assets. $\mathrm{kpmg} / \mathrm{content} / \mathrm{dam} / \mathrm{kpmg} / \mathrm{ng} / \mathrm{pdf} /$ tax/ng-the-national-petroleum-policy.pdf> (last accessed 8 November 2021).

97 Ibid.

98 Ibid.

99 Ibid.

100 Ibid.

101 See Union Bank of Nigeria Plc and Another $v$ Ifeoluwa Nigeria Enterprises Ltd [2006] LCN/2055 (CA); D Olawuyi and Z Tubodenyefa "Review of the Environmental Guidelines and Standards for the Petroleum Industry in Nigeria (EGASPIN)" (2018, OGEES Institute, Afe Babalola University, Ado Ekiti, Nigeria).

102 See Constitution, sched II, item 39.

103 "Local content policies", above at note 6 at 8 . 
the environmental assessment process. ${ }^{104}$ The extent of the consultation depends on the type of project. For example, a project might affect indigenous land used for spiritual purposes. ${ }^{105}$ The obligation to consult is embedded in the twin principles of legal and social licence to operate, and the protection of fundamental rights under the Constitution. ${ }^{106}$ The implication is that the "duty to consult" must be carried out in good faith and utmost integrity, strengthening the corporate-community nexus and shared value system so that companies can operate without hinderance or rejection by the local community. Furthermore, responsibility for the duty to consult is incumbent upon all parties: the state, corporation and community. For example, companies are obliged to ensure that any information on an ongoing project is readily available and easily accessible to the host communities. This is in line with Kemp's model. ${ }^{107}$ It also entails preventing, avoiding, mitigating and addressing any concerns raised by the host communities before a project commences. ${ }^{108}$

Critics of participatory development have noted how this concept can lead to a biased and illegitimate exercise of power, thereby creating a sort of hegemony. ${ }^{109}$ Cook and Kothari argue that empowering local communities to participate in the extraction and development of resources may turn out to be tantamount, in Foucaultian terms, to subjection, in the sense that communities become embroiled in strategies that ultimately empower companies, even though they are presented as favourable to communities. ${ }^{110}$ While it can be a form of political control, ${ }^{111}$ a participatory approach essentially does not epitomize the de-politicization of development. Rather, it opens up a continuous process of engagement with key stakeholders. ${ }^{112}$ The key question is how to embolden a more all-encompassing, participatory approach in decision-making processes, which takes into cognizance the multiplicity of viewpoints on environmental issues.

104 Environmental Impact Assessment Act 1992, sec 2.

105 Id, sec 2(2)(b).

106 See N Echefu and E Akpofure "Environmental impact assessment in Nigeria: Regulatory background and procedural framework" in UNEP EIA Training Resource Manual (Law, policy and institutional arrangements) 63, available at: <https://www.iaia.org/pdf/casestudies/EIANigeria.pdf> (last accessed 8 November 2021).

107 Kemp et al "Just relations and companies", above at note 51.

108 Ibid.

109 B Cooke and U Kothari (eds) Participation: The New Tyranny? (2001, Zed Books).

110 Ibid.

111 G Williams "Evaluating participatory development: Tyranny, power and (re)politicization" (2004) 25/3 Third World Quarterly 557.

112 D Dodman and D Mitlin "Challenges for community-based adaptation: Discovering the potential for transformation” (2013) 25/5 Journal of International Development 640, noting the importance of local involvement in project planning and implementation; I Kapoor The Postcolonial Politics of Development (2008, Routledge), arguing for a softer political strategy that could lead to enhanced democratic dialogue. 
To secure the social legitimacy of corporate actors, it is the expectation that these actors contact host communities through their elected leadership and inform the community of proposed projects. Thus, to ensure maximum participation and information-sharing, host communities must be given relevant information at appropriate fora and businesses must address any concerns or questions they raise. These concerns include human rights violations, the extent of local participation in project execution, and employment generation and procurement. The desire for local content policies is anchored on the need to provide full information and disclosure to those who will be impacted by a project, giving these stakeholders an opportunity to recognize concerns that might arise, opening the way to developing commitments in response to local input and, in most cases, addressing real concerns rather than regulatory procedures. Moreover, consultation in the Niger Delta reveals a two-way community / company communication process and project plan that is tailored to the local context.

The duty to consult with local communities is fundamental to the environmental assessment process under the Environmental Assessment Act. Businesses are obliged to include all relevant stakeholders in the planning, signing and execution process so that their concerns are known and addressed before irreversible evaluations and actions are made. It is important to add that deference to a negotiated strategy with host communities gives rise to the importance of a global memorandum of association, commonly used in Nigeria. These memoranda are negotiated contracts between companies and host communities. ${ }^{113}$ Due to their private nature, it is difficult to ascertain the extent of inclusionary strategies, such as adequate consultation, employment opportunities and continuous training.

The inherent weakness in Nigeria's approach to LCRs is evident in the fact that foreign investors do not have to commit to keep the head office of their Nigerian business in Nigeria. Apart from the provision that a non-Nigerian may invest and participate in the operation of any enterprise in Nigeria, ${ }^{114}$ there is no requirement in respect of the headquarters of a foreign enterprise in Nigeria for the purpose of safeguarding local content. ${ }^{115}$ To further strengthen LCRs in Nigeria, requirements for continuous hiring, "infusion of capital" in local businesses and stiff penalties against dismissals or redundancies, are imperative. ${ }^{116}$ Arguably, foreign companies in Nigeria

113 E Oshionebo "Community development agreements as tools for local participation in natural resource projects in Africa” in I Feichtner, M Krajewski and R Roesch (eds) Human Rights in the Extractive Industries: Transparency, Participation, Resistance (2019, Springer Publishing) 77. They are also referred to as impact benefit agreements or community development agreements.

114 See Nigerian Investment Promotion Commission Act 1995, secs 17 and 20.

115 Companies and Allied Matters Act 1990 (CAMA), secs 36 and 547. CAMA generally requires a foreign company to be incorporated as a separate entity and have an established place of business in Nigeria. See further id, secs 54, 56 and 547.

116 "Local content policies in minerals-exporting countries: Case studies" (Working Party of 
have stymied SMEs, depriving them of the necessary education and training to bid for complex tenders, as well as support mechanisms to thrive in supply chains. ${ }^{117}$ Nigeria can progressively realize the potential inherent in local content laws by ensuring that foreign enterprises see their partnership with local suppliers as a joint venture arrangement rather than a superior-inferior contractual arrangement. This will, undoubtedly, safeguard the local supply chain so that it benefits from the local content policies. For example, while local content law in Nigeria aims to reduce the proportion of expatriates in the senior management of companies, there is contention about the lack of enforcement of the law and the corrupt tendencies of state agencies. ${ }^{118}$ The law should go further. A larger percentage of senior executives of foreign businesses operating in Nigeria must constitute Nigerians. Furthermore, foreign investors must satisfy the government that any investment will be of "net benefit to Nigeria". Satisfaction of this requirement would be evident in employment quotas, the degree of participation of Nigerians in a business, and the effect of investment on productivity, technological development and product innovation.

The determination of LCRs has the potential to generate varied approaches to extractive resource governance. First, while LCRs improve contributory legitimacy through responsiveness to local concerns, ${ }^{119}$ they also have the capability to generate productive legitimacy, through policy orientation and enhancement that work effectively and resonate with citizens' "ideals, values and identity". ${ }^{120}$ A proactive and practical realization of LCRs increases the level of corporate legitimacy and guarantees an SLO, as citizens consider themselves to be in a position of control and influence over project execution. This is more important when corporate decisions are made that incorporate citizens' participation, which leads to "better (or worse) environmental

contd

the Organisation for Economic Co-operation and Development Trade Committee, 2 June 2017) at 23, available at: <http://www.oecd.org/officialdocuments/publicdisplaydo cumentpdf/?cote=TAD/TC/WP(2016)3/PART2/FINAL\&docLanguage=En $>$ (last accessed 8 November 2021); K Abdel-Barr and K MacMillan "Canada" in T Eldridge (ed) The International Comparative Legal Guide to: Mining Law 2019 (6th ed, 2018, Global Legal Group) 19, available at: <https://www.lawsonlundell.com/media/news/588_ML19_ Chapter-4-Canada.pdf> (last accessed 8 November 2021).

117 Eboh "Local content, local troubles", above at note 21.

118 C Houeland "Casualisation and conflict in the Niger Delta: Nigerian oil workers' unions between companies and communities” (2015) 224 Third World Review 25.

119 H Kriesi Democracy in the Age of Globalization and Mediatization (2013, Palgrave Macmillan); FW Scharpf "Problem-solving effectiveness and democratic accountability in the EU" (Max Planck Institute for the Study of Societies working paper 03/1, February 2003), available at: <https://www.mpifg.de/pu/workpap/wp03-1/wp03-1.html> (last accessed 8 November 2021); A Bächtiger and J Parkinson Mapping and Measuring Deliberation: Towards a New Deliberative Quality (2019, Oxford University Press); RF Mendonça, SA Ercan and $\mathrm{H}$ Asenbaum "More than words: A multidimensional approach to deliberative democracy" (2020) 1/20 Political Studies 2.

120 Jagers et al "The impact of local participation", above at note 93 at 127. 
outcomes". ${ }^{121}$ Besides, LCR objectives guarantee that skill transfers are better adapted to local socio-economic, cultural and political realities. In other words, if people realize that policy objectives inculcate a joint or shared approach to development, then people will demand that any business is considered a joint effort and not a business versus community situation. A nonrealizable LCR can activate public resistance and resentment against policy proposals.

It is important to note that sustainably crafted legislation, without productive and progressive realization, will be futile. ${ }^{122}$ Factors that impede this realization range from expensive litigation processes, protectionist policies, citizenship awareness, ${ }^{123}$ and conflict between local communities and extractive companies, resulting in numerous remonstrations and protests. ${ }^{124}$ While Nigeria is not immune to these challenges, the enactment of LCRs as legally enforceable documents could offer potential benefits to local industries. They would also provide the basis for economic diversification, ${ }^{125}$ thereby increasing the chances of Nigeria being able to withstand future oil price volatility, as has been evident in recent times. ${ }^{126}$

\section{CONCLUSION}

Despite its progressive nature, the local content policy on value creation in the Nigerian oil sector is uncertain. Examining the efficiency of local content polices is indispensable to realizing considerable local added value. The state and investors must comply with LCRs, providing the public and private sectors with adequate investment in skills training and development. ${ }^{127}$

121 J Newig, E Challies and NW Jager "The environmental performance of participatory and collaborative governance: A framework of causal mechanisms" (2018) 46/2 Policy Studies Journal 269 at 269.

122 See generally I Ramdoo Designing Local Content Policies in Mineral-Rich Countries (2018, Intergovernmental Forum on Mining, Minerals, Metals and Sustainable Development), available at: <https://www.iisd.org/sites/default/files/publications/local-content-policiesmineral-rich-countries.pdf> (last accessed 8 November 2021).

123 D Stonehouse "Canada's oilfield services exporters need to be aware of local content rules when targeting new markets" (11 July 2018) JWN Energy, available at: <https://www. jwnenergy.com/article/2018/7/11/canadas-oilfield-services-exporters-need-be-aware-/> (last accessed 8 November 2021).

124 G Hufbauer and JJ Schott Local Content Requirements: A Global Problem (2013, Peterson Institute Press).

125 R Hart and D Hoogeveen "Introduction to the legal framework for mining in Canada" (18 July 2012) MiningWatch, Canada, available at: < https://miningwatch.ca/publications /2012/7/18/introduction-legal-framework-mining-canada> (last accessed 8 November 2021, noting the procedure on how communities and indigenous people are consulted about mineral developments, and where consent is recognized.

126 JS Ovadia "Is natural resource-based development still realistic for Africa?" (10 February 2016), available at: <https://www.e-ir.info/2016/02/10/is-natural-resource-based-develo pment-still-realistic-for-africa/> (last accessed 8 November 2021).

127 "Public-private dialogue for specific sectors: Extractive industries" (World Bank Group 
Extractive companies must communicate with local communities and other stakeholders about disparities in requests for labour at different stages of an extractive project. This will create some degree of trust between investors and local communities.

State-investor responsibility here denotes that trust allows investors to operate without hindrance. Thus, communities must be included in project monitoring and evaluation, open and transparent disclosure mechanisms, and effective community participation, including women and vulnerable community members. There is no doubt that these will reduce the recurring remonstrations between communities and extractive companies, and cultivate a sustainable relationship that advances mutual trust among stakeholders. ${ }^{128}$

The lack of local community consultation and participation in resource contract negotiations and the decision-making process between state and investors is disturbing. For instance, Nigeria's extractive laws do not provide any role for local communities in the decision-making process. Despite the ingenuity of the environmental impact assessment and other laws, they fall far short of the needed dogmatic approach to LCRs. First, while they guarantee that deference should be shown to citizens in project execution, they do not indicate whether local interests should be given more input during the development process or determine when it is appropriate to stop development when those interests become threatened. A heightened "power of veto" will ensure that the influence of local actors in project management will inevitably lead to a perception that extractive projects, for example, are positive. Where local actors do not see an increased role, this triggers resentment and remonstrations against any development project. Consequently, the legitimacy of LCRs is hinged on the premise that apparent levels of power in decisionmaking processes and the scope of engagement of local communities are crucial in supporting and legitimizing any developmental project. Amassing investment in the "local democratization of decision-making" will generate the possibility for host communities to expand their participatory control, resulting in effective LCR policies and regulations.

Obtaining an SLO guarantees the sharing of values and benefits at local and national levels. For instance, a contract between host communities and extractive companies in the form of a global memorandum of association, impact benefit agreement or community development agreement, creates a relationship between stakeholders, integrates local experiences, and offers the public opportunities to provide their views and reactions to ongoing projects. Corporate-community extractive investments create a shared value

contd

Nuts \& Bolts technical guidance), available at: <http://documents.worldbank. org/curated/en/444581504190566893/pdf/119240-BRI-PUBLIC-6p-IFCICNutsBoltsPPDExt ractivedigital.pdf> (last accessed 8 November 2021).

$128 \mathrm{~J}$ Gorski "Social licence to operate (SLO) in the extractive and energy sectors: Introduction" (2020) 18/1 Oil, Gas and Energy Law 1. 
system and effective partnerships for local stakeholder development. The local community's participation is indispensable to understanding the local context. Citizens must lead their own development and build their own institutions. When participation fails, the community is left with no choice but to resist any projects that may be sited on their land. Consequently, encouraging local community participation reduces conflict in the resource zones.

Comprehensive consultation continues to be a herculean task for most local communities in Nigeria. This is due to leadership structures that are characterized by power struggles, making it difficult for companies to engage with community leaders. Linked to this is the fact that key community stakeholders are deprived of involvement in the participatory process, due in part to cultural hegemonic structures. Well designed and implemented LCRs are catalysts for structural development. To achieve the sustainable development of its extractive sector, Nigeria must devise a resolute state-led effort and determination to stimulate economic growth and development.

\section{CONFLICTS OF INTEREST}

None 